\author{
JOANNA JAKÓBIK, MACIEJ PABIJAN \\ Zakład Anatomii Porównawczej \\ Instytut Zoologii i Badań Biomedycznych \\ Wydzial Biologii \\ Uniwersytet Jagiellonski \\ Gronostajowa 9, 30-387 Kraków \\ E-mail: maciej.pabijan@uj.edu.pl
}

\title{
PANDEMIE WŚRÓD PŁAZÓW
}

\section{MASOWE WYMIERANIE PŁAZÓW}

Kryzys bioróżnorodności spowodowany masowym wymieraniem gatunków dotyczy większości aktualnie żyjacych grup organizmów (CEBALlos i współaut. 2015). Wśród zwierzat kręgowych zjawisko to najdotkliwiej odczuwaja płazy (Amphibia) (IUCN 2021). Na Ziemi znanych jest aktualnie ponad 8300 gatunków tych zwierząt (AmphibiaWeb, https://amphibiaweb.org/index.html), $z$ czego $41 \%$ jest zagrożonych wyginięciem (IUCN 2021). Za duża skalę tego zjawiska odpowiada wiele czynników, często działających równocześnie, powodujacych wymieranie lokalnych populacji płazów (PABIJAN i współaut. 2020).

Zwiększona wrażliwość płazów na wymieranie wynika bezpośrednio $z$ ich fizjologicznego uzależnienia od środowiska wodnego (WeLlS 2010). Cienka, wilgotna i silnie unaczyniona skóra tych zwierząt jest przepuszczalna dla wody i gazów oraz posiada liczne gruczoły śluzowe, których zadaniem jest m.in. ochrona przed wyschnięciem. Inna cechą uzależniajacca płazy od środowiska wodnego jest ich sposób rozmnażania. Jaja płazów nie maja twardej otoczki oddzielajacej je od środowiska zewnętrznego, chroniącej przed utrata wody. W rozwoju wielu gatunków występuje wolnożyjąca, wodna larwa, oddychajaca za pomoca skrzeli, co powoduje uzależnienie ich rozwoju od stałego dostępu do wody (FEDER i BURGGRen 1992). Powyższe cechy determinuja środowisko życia płazów.
Najwięcej gatunków występuje w wilgotnych lasach, zwłaszcza w górzystych, zalesionych częściach krajów tropikalnych, gdzie również obserwuje się najszybsze tempo wymierania tych zwierząt (CEBALlos i współaut. 2020).

Zanikanie płazów powoduja głównie czynniki antropogeniczne. Najważniejsza przyczyna jest degradacja i utrata podstawowych siedlisk. Osuszanie terenów podmokłych, deforestacja, postępująca urbanizacja oraz budowa dróg znacznie przyczynily się do zmniejszenia liczby populacji i fragmentacji wcześniej zwartych zasięgów wielu gatunków płazów (GALLANT i współaut. 2007). Groźne w skutkach okazuja się globalnie zachodzace zmiany klimatyczne oraz wzrastajace zanieczyszczenie środowiska pestycydami i metalami ciężkimi (COLLINS i STORFER 2003). Celowe bądź nieświadome introdukcje gatunków obcych, w tym także płazów, może silnie ingerować w lokalne biocenozy na skutek np. intensywnego drapieżnictwa lub konkurencji $\mathrm{z}$ rodzimymi gatunkami (KRAUS 2015). Wykorzystanie płazów do celów medycznych i laboratoryjnych, odłów i hodowla w celach kulinarnych, a także coraz szerzej uprawiana terrarystyka i zwiazany $z$ nia handel żywymi osobnikami, doprowadziły do nadmiernej eksploatacji niektórych gatunków (Collins 2010).

Ze wzmożonym handlem płazów zwiazany jest kolejny czynnik przyczyniający się do ich wymierania. Wraz z żywymi płazami roznoszone są również ich patogeny, wywołujące choroby niebezpieczne dla tych zwierzat 
(Kolby i współaut. 2014, NGUYEN i współaut. 2017, O’HANlon i współaut. 2018). Patogeny te, pierwotnie występujace $\mathrm{w}$ izolowanych regionach, głównie Azji południowo-wschodniej (LAKING i współaut. 2017, O'HANLON i współaut. 2018), stanowią wielkie zagrożenie, gdy infekuja populacje gatunków, które wcześniej nie miały $z$ nimi do czynienia. Do najgroźniejszych patogenów należą mikroskopijne grzyby Batrachochytrium sp. z rodziny skoczkowców (Chytridiomycota) oraz wirusy $z$ rodzaju Ranavirus (Iridoviridea). Ich rozprzestrzenienie wywołało wśród wielu populacji płazów drastyczne zmniejszenie liczebności, co dla niektórych gatunków było przyczyna całkowitego zaniknięcia ze środowiska naturalnego, a nawet wymierania (SCHEELE i współaut. 2019, MARTEL i współaut. 2013). Patogeny te nadal poszerzaja swoje zasięgi, natomiast świadomość tego zjawiska zarówno wśród społeczeństwa, jak i lokalnych władz wciaż jest znikoma. Przybliżenie $\mathrm{i}$ rozpowszechnienie informacji dotyczacych pandemii panujacych w świecie płazów może być kluczowe dla ograniczenia dalszego rozprzestrzeniania groźnych patogenów. Poniżej przedstawiamy doniesienia ostatnich lat na temat rozmieszczenia najważniejszych patogenów płazów, prognozy dalszego rozprzestrzeniania i perspektywy zachowania płazów w obliczu trwajacych pandemii.

\section{BATRACHOCHYTRIUM DENDROBATIDIS}

W latach 1996-1998 w ogrodzie zoologicznym w Waszyngtonie obserwowano przypadki śmiertelnej infekcji skóry u płazów. Czynnikiem zakaźnym wywołujacym chorobę okazał się mikroskopijny grzyb $z$ gromady skoczkowców (Chytridiomycota) - Batrachochytrium dendrobatidis $(B d)$ (LONGCORE i współaut. 1999). Patogen ten jest ściśle zwiąany ze środowiskiem wodnym. To w nim zoospory (ruchliwe zarodniki grzyba posiadające witkę) osiadaja na skórze płaza i przenikaja do najbardziej zewnętrznej warstwy naskórka, gdzie odbywa się reszta cyklu życiowego patogenu (Ryc. 1) (BERGER i współaut. 2005). Następstwem rozrostu

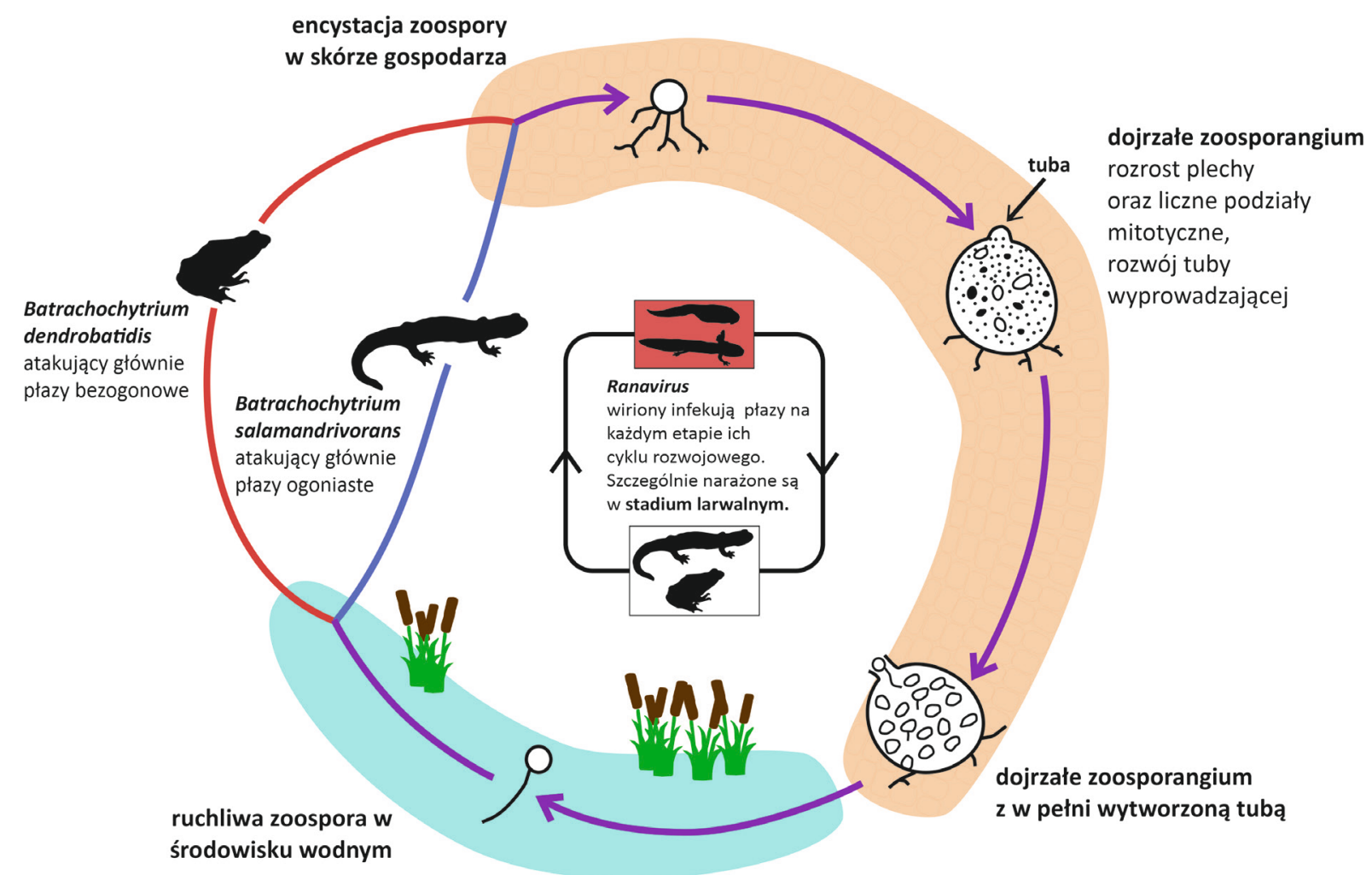

Ryc. 1. Schemat przedstawiający cykl życiowy grzybów z rodzaju Batrachochytrium i wirusów z grupy Ranavirus, $z$ wyróżnieniem rzędów płazów atakowanych przez dany patogen. Zoospory znajdujące się w wodzie osiadaja na skórze płaza i przenikają do najbardziej zewnętrznych (w przypadku $B d$ ) lub głębszych (w przypadku Bsal) warstw naskórka, gdzie encystuja i przechodzą liczne podziały mitotyczne. Prowadzi to do rozrostu plechy w dojrzałe zoosporangium oraz powstania nowych zoospor. Powstaje również tuba wyprowadzająca zoospory. Przy korzystnych warunkach zewnętrznych tuba otwiera się, a zoospory opuszczają zoosporangium. Na rycinie widoczny również uproszczony schemat infekcji wirusem $z$ rodzaju Ranavirus. Transfer patogenu następuje głównie poprzez bezpośredni kontakt $z$ zainfekowanym osobnikiem. 
plechy grzyba w skórze płazów jest chytridiomikoza, choroba wywoływana przez $B d$. Odbywający się w skórze cykl życiowy patogenu wywołuje szereg zmian w jej funkcjonowaniu jako organu istotnego dla wymiany gazowej oraz transportu wody i jonów. Nieprawidłowości w tych procesach zakłócaja gospodarkę jonowa, co może być przyczyna zaburzeń pracy serca i układu nerwowego, a w konsekwencji śmierć gospodarza (VoYLES i współaut. 2009). Dodatkowym objawem jest hiperkeratoza (nadmierne zrogowacenie) naskórka, powodujaca jego zwiększone nawarstwianie i złuszczanie. Prowadzi to do odpadania dużych płatów skóry i tworzenia się otwartych ran. Powoduje to dodatkowe osłabienie chorego zwierzęcia i zwiększa ryzyko ponownych infekcji (BERGER i współaut. 2005).

Najnowsze badania sugeruja, że $B d$ jest gatunkiem naturalnie wystepujacym na terenie Azji Wschodniej i stamtąd został zawleczony w inne miejsca na świecie (O'HANLON i współaut. 2018). Najtragiczniejsze w skutkach okazało się pojawienie się tego patogenu w Ameryce Południowej, Środkowej i Australii, miejscach charakteryzującymi się wysoką bioróżnorodnością płazów i licznymi gatunkami endemicznymi. Na tych terenach wystapiło najwięcej przypadków masowego wymierania populacji płazów powiazanych $z$ infekcja $B d$ (SCHEELE i współaut. 2019). Obecnie $B d$ został stwierdzony na wszyst- kich kontynentach, $\mathrm{z}$ wyjątkiem Antarktydy. Patogen ten okazał się bezpośrednim zagrożeniem dla światowej populacji płazów. Przyczynił się do znaczącego zaniku około 500 gatunków, a 90 z nich uważa się za wymarłe w środowisku naturalnym. Stanowi to największa udokumentowana utratę bioróżnorodności, która można przypisać patogenowi. Czołowe fale światowej ekspansji $B d$ przypadaja na pierwsza połowę XX w. (O’HANLON i współaut. 2018), czyli na okres wielkiego przyspieszenia globalizacji gospodarki. Przypuszcza się, że zainfekowane płazy mogły zostać nieumyślnie rozprowadzone wraz ze wzmożonym transportem towarów. Ponadto, w wielu krajach rozpoczęto masową hodowlę gatunków, takich jak żaba ryczaca (Lithobates catesbeianus) w celach konsumpcyjnych, czy platana szponiasta (Xenopus laevis) do badań medycznych. Oba gatunki zaliczane sa do aklinicznych rezerwuarów $B d$, u których dochodzi do infekcji, ale bez objawów chorobowych. Półotwarte hodowle żab, a także celowe wypuszczanie płazów przyczyniło się do przenikania $B d$ do lokalnych populacji, stając się źródłem nowych infekcji (WELDON i współaut. 2004, GREENSPAN i współaut. 2012, VREDENBURG i współaut. 2013, MIAUD i współaut. 2016b). W drugiej połowie XX w. skala wymierania płazów na skutek infekcji $B d$ nabrała masowego i globalnego charakteru. Wówczas doszło do wymierania gatunków płazów, za-

Tabela 1. Wybrane doniesienia na temat masowej śmiertelności płazów w Europie wywołanej pojawieniem się patogenów płazów Batrachochytrium dendrobatidis $(B d), B$. salamandrivorans $(B s a l)$, oraz różnych gatunków ranawirusów $(R v)$. W Polsce nie odnotowano jeszcze przypadków wymierania populacji wywołanej przez te patogeny.

\begin{tabular}{llll}
\hline Państwo & Gatunek & Patogen & Literatura \\
\hline Belgia & Salamandra salamandra & Bsal & STEGen i współaut. 2017 \\
Dania & Pelophylax esculentus & $\mathrm{Rv}$ & ARIEL i współaut. 2009 \\
Francja & Rana temporaria & $\mathrm{Rv}$ & MiAud i współaut. 2016a \\
Hiszpania & Alytes obstetricans & $\mathrm{Bd}, \mathrm{Rv}$ & Bosch i współaut. 2001 BAL- \\
& & & SEIRO i współaut. 2010 \\
Hiszpania & Bufo bufo & $\mathrm{Bd}, \mathrm{Rv}$ & BOSCH i MARTínEZ-SOLANO 2006 \\
Hiszpania & Ichthyosaura alpestris & $\mathrm{Rv}$ & BALSEIRO i współaut. 2010 \\
Hiszpania & Salamandra salamandra & $\mathrm{Bsal}$ & MARTEL i współaut. 2020 \\
Holandia & Salamandra salamandra & $\mathrm{Bsal}$ & MARTEL i współaut. 2013 \\
Niemcy & Ichthyosaura alpestris & $\mathrm{Bsal}$ & SCHMELLER i współaut. 2020 \\
Niemcy & Salamandra salamandra & $\mathrm{Bsal}$ & SCHULz i współaut. 2020 \\
Wielka Brytania & Rana temporaria & $\mathrm{Rv}$ & TEACHER i współaut. 2010 \\
Węgry & Bombina variegata & $\mathrm{Bd}$ & HARMOs i współaut. 2021 \\
\hline
\end{tabular}


mieszkujących niemal nietknięte ręka ludzka lasy deszczowe, takich jak ropucha złota (Incilius periglenes) w Monteverde na Kostaryce i żoładkorody (Rheobatrachus) w północnowschodniej Australii, które stały się symbolem pandemii wywołanej przez $B d$. W obecnych czasach sporadycznie notujemy zaniki płazów na skutek chytridiomikozy wywołanej $B d$ (Tabela 1). Nie wiadomo, czy jest to skutek wytworzenia większej oporności/tolerancji u płazów, czy ma to związek $z$ wciaż słaba wykrywalnościa choroby $\mathrm{w}$ terenie. Niestety szczegółowe badania wysoce podatnych na infekcje gatunków, takich jak płazy $z$ rodzaju pętówek (Alytes), pokazuja niedawne i znaczne zaniki populacji na rozległych geograficznie obszarach, korelujące $z$ obecnościa patogenu (np. THUMSOVÁ i współaut. 2021). Ostatnio opisany przypadek masowej śmiertelności kumaków górskich na Węgrzech na skutek infekcji $B d$ (HARMOS i współaut. 2021) świadczy o wcią̇ aktualnym zagrożeniu, jaki patogen ten stanowi dla wielu gatunków płazów (Tabela 1). Ostrożne prognozy szacuja 90\% spadki liczebności populacji wśród kolejnych 124 gatunków płazów wywołane pojawieniem się $B d$ (SCHEELE i współaut. 2019).

Jak wyglada sytuacja w Polsce? Pierwsze doniesienia o występowaniu patogenu $\mathrm{w}$ kraju pochodza z 2010 r. (SURA i współaut.
2010). W 2017 r. obecność $B d$ została potwierdzona i dobrze udokumentowana na 2 stanowiskach w zachodniej części kraju (KoLENDA i współaut. 2017). Najnowsze dane przesiewowe ze 115 stanowisk i 1112 przebadanych osobników wykazały powszechne występowanie $B d$ na terenie kraju (PALOMAR i współaut. 2021). Patogen wykryto na $40 \%$ stanowisk badawczych, a także w dwóch zamkniętych hodowlach. Ogólna chorobowość (prewalencja) została oszacowana na poziomie $14 \%$, co oznacza, że co siódmy przebadany płaz był zainfekowany. Te alarmujace statystyki znajduja się w górnej granicy częstości infekcji $B d$ notowanych w innych krajach Europy Środkowej. Przykładowo, przekraczaja dwukrotnie prewalencję $B d$ w Niemczech czy na Węgrzech (OHST i współaut. 2013, VÖRÖS i współaut. 2018). Spośród 9 gatunków płazów, u których wykryto $B d$, największa liczbę zainfekowanych osobników wykryto u żab wodnych (Pelophylax esculentus) i kumaków górskich (Bombina variegata) - odpowiadały one za $75 \%$ wszystkich infekcji, co sugeruje dużą rolę tych dwóch gatunków (Ryc. 2) jako rezerwuarów patogenów w środkowoeuropejskich siedliskach słodkowodnych. Na terenie Polski nie zarejestrowano jeszcze masowego wymierania populacji płazów $z$ powodu infekcji $B d$ (PALOMAR i współaut. 2021), choć znane

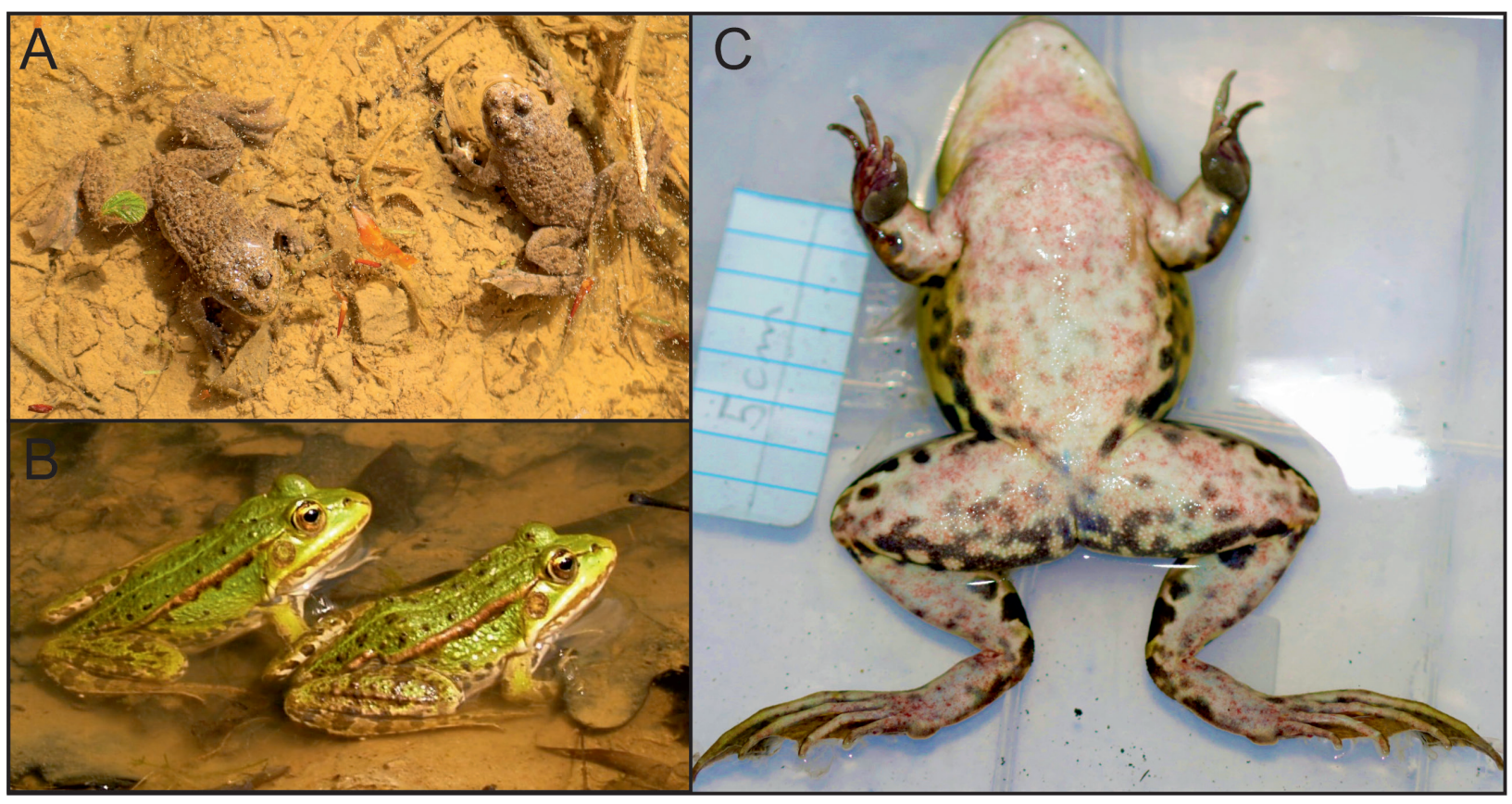

Ryc. 2. Przykłady dwóch gatunków płazów, u których wykryto największą liczbę infekcji Batrachochytrium dendrobatidis w Polsce: (A) kumak górski Bombina variegata oraz (B) żaba wodna Pelophylax esculentus. Fotografia (C) przedstawia martwego samca żaby śmieszki Pelophylax ridibundus z Krakowa, z licznymi drobnymi ranami i przekrwieniami widocznymi na brzusznej (a także grzbietowej) powierzchni ciała. Osobnik ten charakteryzował się apatią i odrętwieniem tylnych kończyn krótko przed śmiercią. Badania diagnostyczne wykazały infekcję B. dendrobatidis o znacznej intensywności (fot. M. Pabijan). 
sa pojedyncze przypadki śmiertelności płazów powiazanych $z$ intensywna infekcja $B d$ (M. Pabijan, J. Jakóbik, dane niepublikowane) (Ryc. 2).

Do postępu w zrozumieniu epidemiologii $B d$ przyczyniło się zsekwencjonowanie genomów 43 izolatów tego patogenu. Odkryto, że $B d$ nie jest genetycznie jednolitym gatunkiem, jak wcześniej sądzono, lecz składa się $z$ co najmniej pięciu odmiennych linii ewolucyjnych (FARRER i współaut. 2011, Rosenblum i współaut. 2013, O'HANLON i współaut. 2018, BYRNE i współaut. 2019). Linie te różnia się wiekiem, rozmieszczeniem i wirulencją. Najgroźniejsza jest szeroko rozpowszechniona, panzootyczna (dotykajaca wielu gatunków płazów na dużym obszarze) linia BdGPL (ang. global panzootic lineage), która stoi za większościa zaników płazów na wszystkich zamieszkanych przez nie kontynentach. Pozostałe linie: BdASIA1/BdCH, BdASIA2 / BdBrazil, BdASIA3, BdCape, maja bardziej ograniczone zasięgi i są na ogół mniej szkodliwe dla płazów, aczkolwiek niektóre $z$ nich wywołuja śmiertelna chytridiomikozę w określonych warunkach (FARRER i współaut. 2011, BECKER i współaut. 2017). $\mathrm{W}$ wielu regionach występuja dwie, lub więcej, linii ewolucyjnych $B d$, niekiedy w tej samej populacji płazów (BYRNE i współaut. 2019). Współwystępowanie odmiennych linii ewolucyjnych $B d$ poszerza zakres żywicieli, u których może pojawić się choroba, a także stwarza warunki do rekombinacji pomiedzy liniami $B d, z$ trudnymi do przewidzenia konsekwencjami dla płazich gospodarzy (GREENSPAN i współaut. 2018, BYRNE i współaut. 2019). W Europie 90\% oznaczonych izolatów $B d$ przyporzadkowano do linii BdGPL, $10 \%$ do BdCape (powszechna także w południowej i środkowej Afryce), a kilka izolatów do linii BdASIA1/BdCH (BYRNE i współaut. 2019). Nie prowadzono jak dotąd badań nad identyfikacja linii ewolucyjnych $B d$ występujacych w Polsce. Brak informacji wyznacza palaca potrzebę badań w kierunku ustalenia, które szczepy patogenicznego grzyba obecne sa w kraju.

\section{BATRACHOCHYTRIUM SALAMANDRIVORANS}

Drugim patogenem, spokrewnionym $Z$ Batrachochytrium dendrobatidis, zagrażającym światowej populacji płazów, jest $B$. salamandrivorans (Bsal) (MARTEL i współaut. 2013). Patogen ten zasługuje jednak na szczególną uwage $z$ powodu wywołanej przez niego wysokiej śmiertelności wśród płazów ogoniastych na terenie Europy zachodniej. Gatunek ten opisano w 2013 r. po drastycznym spadku liczebności populacji salamandry plamistej (Salamandra salamandra) w Holandii w 2010 r. Infekcja spowodowała redukcję liczebności populacji o 96\% w porównaniu ze stanem sprzed epidemii (MARTEL i współaut. 2013). Salamandry znajdywano martwe w trakcie badań terenowych, zaś eksperymentalne wystawienie na kontakt z Bsal w warunkach laboratoryjnych spowodowało śmierć badanych osobników po 7 dniach. Cykl życiowy Bsal, a także obraz kliniczny choroby spowodowany obecnością patogenu, sa podobne jak w przypadku Bd (Ryc. 1). Różnicą jest występowanie encystujących zoospor, mogacych przetrwać w środowisku znacznie dłużej niż zoospory $B d$. Zwiększa to szanse Bsal na zainfekowanie kolejnego osobnika (STEGEN i współaut. 2017). Chytridiomikoza wywołana Bsal objawia się nekroza skóry w licznych, niewielkich ogniskach w różnych częściach ciała płaza. Z ognisk tych moga powstać otwarte, głębokie rany. Ponadto, chore zwierzęta sa wychudzone, maja problemy $z$ poruszaniem się i nie reagują na bodźce ze środowiska zewnętrznego (MARTEL i współaut. 2013). Warto zaznaczyć, iż patogen ten najpewniej już wcześniej był obecny w północno-zachodniej Europie, o czym świadcza informacje o przypadku masowej śmiertelności salamander $z$ okolic miasta Roetgen na granicy niemiecko-belgijskiej w 2004 r. (LÖTTERS i współaut. 2020). Obraz histopatologiczny martwych salamander $z$ tego incydentu jest porównywalny ze zmianami skórnymi zachodzącymi podczas infekcji Bsal (LÖTTERs i współaut. 2020).

Najprawdopodobniej Bsal jest patogenem endemicznym we wschodniej Azji, gdzie został wykryty u różnych przedstawicieli rodziny salamandrowatych: Tylotriton sp. czy $P a-$ ramesotriton sp. (LAKING i współaut. 2017), u których jednak nie zauważono objawów chorobowych. Za inwazje Europy zachodniej przez Bsal odpowiada nierozważny handel azjatyckimi gatunkami płazów, zarówno ogoniastymi, jak i bezogonowymi (NGUYEN i współaut. 2017). Dotychczas nie stwierdzono Bsal w innych miejscach poza Azja i Europa, a jego zasieg w Europie niestety rozszerza się. Stwierdzono obecność Bsal m.in. w Belgii, Holandii i w Niemczech (Tabela 1) (SPITZEN-VAN DER SluiJs i współaut. 2016). Nowe stanowiska wykryto również w Bawarii (Niemcy) (SCHMELLER i współaut. 2020, THEIN i współaut. 2020) i Hiszpanii (LASTRA GONZÁLEZ i współaut. 2019, MARTEL i współaut. 2020). Najnowsze badania $z$ regionu Półwyspu Iberyjskiego sugeruja, że z 11 gatunków występujących tam płazów ogoniastych aż 10 może być podatnych na infekcje Bsal. Spośród nich, 5 narażonych jest na wymieranie populacji porównywalne $z$ zanikiem salamandry plamistej na terenie Holandii. Pojawienie się patogenu w tamtej- 
szych populacjach może więc być katastrofalne w skutkach (Bosch i współaut. 2021). Niestety, warunki ekologiczne w zachodniej Palearktyce sprzyjają rozszerzeniu zasięgu Bsal. Nawet najbardziej konserwatywne modele potencjalnego występowania tego patogenu wskazuja na wiele niezajętych jeszcze regionów, a także nowych żywicieli wśród europejskich płazów ogoniastych (BEUKEMA i współaut. 2018). Potwierdza to niedawna i pierwsza obserwacja śmiertelności traszek górskich (Ichthyosaura alpestris) $\mathrm{z}$ powodu infekcji Bsal w południowej Bawarii (SCHMELler i współaut. 2020) (Tabela 1).

Dalszy monitoring poziomu zainfekowania europejskich populacji płazów ogoniastych jest kluczowy dla wprowadzenia działań prewencyjnych (GILBERT i współaut. 2020). Na terenie Polski nie stwierdzono jeszcze obecności Bsal (LASTRA GonZÁlez i współaut. 2019, PALOMAR i współaut. 2021), natomiast rodzimymi gatunkami płazów narażonymi na śmiertelna infekcję sa głównie przedstawiciele rodziny salamandrowatych: salamandra plamista czy traszka górska, a także endemiczna dla Karpat traszka karpacka (Lissotriton montandoni). Płazy bezogonowe sa prawdopodobnie jedynie wektorem Bsal (STEGEN i współaut. 2017).

\section{RANAVIRUS}

Wirusy $z$ rodzaju Ranavirus ( $R$, rodzina Iridoviridae) zostały po raz pierwszy wyizolowane $\mathrm{w}$ polowie lat 60. XX w. $\mathrm{z}$ tkanek żaby lamparciej (Lithobates pipiens) (GRANOFF i współaut. 1965). Rv jest rodzajem dużych $(105 \mathrm{kbp}, 150 \mathrm{~nm}$ średnicy; rozmiary podobne jak w przypadku SARS-CoV-2) wirusów DNA o przekroju przypominajacym sześciokat (GRAY i współaut. 2009). Wiriony występuja $\mathrm{w}$ dwóch formach: $\mathrm{z}$ otoczka białkowa i bezotoczkowych. Obie formy sa zdolne do zakażenia gospodarza (JANCOVICH i współaut. 2015b). Wirusy te infekuja nie tylko płazy, zarówno bezogonowe, jak i ogoniaste (DASZAK i współaut. 2003), ale również ryby kostnoszkieletowe czy gady. Dotychczas poznano 7 gatunków ranawirusów, z czego 4 sa zdolne do infekowania płazów: Frog virus 3 (FV3), Bohle iridovirus (BIV), Common midwife toad virus (CMTV) i Ambystoma tigrinum virus (ATV) (JANCOVICH i współaut. 2015a, PRICE i współaut. 2017). Każdy z nich przyczynia się do spadków liczebności populacji płazów na świecie (JANCOVICH i współaut. 2015a).

Do infekcji ranawirusem dochodzi głównie $\mathrm{w}$ środowisku wodnym. Kilka godzin po infekcji komórki następuje synteza białek wirusa, co prowadzi do nekrozy lub apoptozy po kilkunastu godzinach po pojawieniu się patogenu w komórce (GRAY i współaut.
2009). Najbardziej charakterystycznym objawem ranawirozy jest pojawienie się licznych krwiaków w silnie unaczynionej skórze płaza; najczęściej znajduja się po brzusznej stronie ciała i w okolicach kończyn. Można je również zaobserwować wokól oczu czy na języku. Innym objawem jest utrata pigmentacji skóry. Następstwem infekcji jest nekroza narządów, takich jak śledziona, nerki czy watroba (MILLER i współaut. 2015). W przypadku gatunków szczególnie wrażliwych na ranawirozę śmierć może nastapić już tydzień po kontakcie $z$ wirusem. Larwy $\mathrm{i}$ płazy $\mathrm{w}$ trakcie metamorfozy wykazuja duża wrażliwość na pojawienie się patogenu, w porównaniu do dorosłych osobników (Ryc. 1) (GRAY i współaut. 2009). Znane sa jednak osobniki, które pomimo obecności wirusa nie wykazuja objawów chorobowych.

Wirusy $z$ rodzaju Ranavirus sa patogenami o globalnym zasięgu. Występuja na wszystkich kontynentach zasiedlonych przez płazy. Szacuje się, że co najmniej 105 gatunków jest podatnych na infekcje tym patogenem (DuFfus i współaut. 2015). Populacje tych zwierzat różnie reaguja na pojawienie się $R v$ : w niektórych infekcja może być przejściowa bez długotrwałych skutków demograficznych, u innych infekcja może mieć przebieg katastroficzny i powodować całkowite wymieranie populacji. Infekcja może również być przewlekła, $z$ epizodycznie pojawiająca się masową śmiertelnością zainfekowanych płazów (TEACHER i współaut. 2010). Szacuje się, że na terenie Ameryki Północnej $48 \%$ przypadków wymierania populacji płazów spowodowanych jest infekcja ranawirusową (GREEN i współaut. 2002). Na terenie Europy patogen ten został po raz pierwszy stwierdzony w latach 80. XX w. Od tego czasu przypadki masowego wymierania populacji wywołanego pojawieniem się $R v$ stwierdzono w Hiszpanii, Danii, Francji i Anglii (Tabela 1) (CAMPBELl i współaut. 2020). Tak jak w przypadku Batrachochytrium, przyczyna globalnego rozprzestrzenienia ranawirusów jest zawleczenie wraz $z$ transportem towarów i nierozważny handel płazami (PRICE i współaut. 2016). Skalę tego zjawiska zobrazowały badania przeprowadzone na lotnisku w Hong Kongu, gdzie zainfekowane $R v$ jest nawet 50\% eksportowanych płazów (KolBY i współaut. 2014). Pojawienie się wirusa stanowi szczególne zagrożenie dla tych gatunków płazów, u których już zaobserwowano spadek liczebności populacji na skutek działania innych czynników, np. fragmentacji czy degradacji siedlisk (DUFFUS i współaut. 2015, EARL i współaut. 2016). W silnie zmienionym krajobrazie Anglii zaobserwowano $80 \%$ spadek liczebności populacji żaby trawnej ( $R$. temporaria) wywołany 
pojawieniem się $R v$ (TEACHER i współaut. 2010). Niedawne pojawienie się patogenu w północnej Hiszpanii i Portugalii drastycznie zmniejszyło liczebności kilkunastu gatunków płazów, powodując lokalne wymieranie niektórych populacji (PRICE i współaut. 2014, RosA i współaut. 2017). W Europie stwierdzono dwa różne gatunki ranawirusów: FV3 występujacy w Wielkiej Brytanii i sporadycznie w Europie kontynentalnej oraz CMTV występujący w Europie zachodniej i środkowej (PRICE i współaut. 2017). Należy jednak podkreślić, że badania nad występowaniem różnych form $R v$ sa na etapie poczatkowym i nasze poglądy o ich rozprzestrzenianiu, a także taksonomii, $z$ pewnościa ulegna zmianie.

Infekcje $R v$ u płazów stwierdzone zostały również na terenie Polski (PALOMAR i współaut. 2021), jednak nie udokumentowano jeszcze przypadku masowego wymierania $Z$ tego powodu. Badania przesiewowe prowadzone w latach 2018-2019 na terenie kraju wykazały infekcję $R v$ u gatunków takich jak: traszka górska (Ichthyosaura alpestris), salamandra plamista (Salamandra salamandra), kumak nizinny (Bombina bombina), kumak górski (B. variegata), żaba jeziorkowa (Pelophylax lessonae), żaba wodna (P. esculentus), żaba śmieszka ( $P$. ridibundus) i żaba trawna (Rana temporaria). Stwierdzone infekcje dotyczyły osobników dorosłych lub młodocianych po metamorfozie i przebiegały bez widocznych objawów zewnętrznych. Stanowisk z zainfekowanymi płazami było stosunkowo mało (2,4\% z 92 miejsc), jednak rozproszone były w całym kraju. Niestety, jak dotąd nie określono gatunku $R v$, a obecność wirusa w Polsce wymaga dalszych badań.

\section{POZOSTAŁE PATOGENY}

Inne chorobotwórcze organizmy powodujące zaniki lokalnych populacji płazów to grzyby $z$ rodziny Saprolegniaceae wywołujace saprolegniozę, przywry $z$ rodzaju Ribeiroia sp. (DASZAK i współaut. 2003), pierwotniaki $z$ grupy Perkinsea (IsIDORO-AYZA i współaut. 2017) oraz herpeswirusy $z$ rodzaju Batrachovirus (ORIGGI i współaut. 2017). Na terenie Stanów Zjednoczonych udokumentowano przypadki masowej śmiertelności płazów wywołane przez Saprolegniaceae i Perkinsea (KIESECKER i współaut. 2001, IsIDORO-AYZA i współaut. 2017). Za zwiększona śmiertelność tych zwierząt odpowiadaja również wirusy $z$ rodzaju Batrachovirus, których negatywne oddziaływanie obserwuje się na terenie Europy (FRANKLINOS i współaut. 2018). Przywry z gatunku Ribeiroia sp., choć wywołuja deformacje rozwojowe u larw płazów, nie sa uważane za czynnik powodujący masowe wymieranie populacji (DASZAK i współaut. 2003). Konieczne sa jednak dalsze badania nad wymienionymi patogenami w celu dokładniejszego oszacowania stopnia zagrożenia dla światowej populacji płazów. Biorąc pod uwage zmiany klimatyczne, a także negatywny wpływ człowieka na środowisko naturalne, zagrożenie ze strony wymienionych patogenów może wzrastać.

\section{PERSPEKTYWY ZACHOWANIA PŁAZÓW W OBLICZU PANDEMII}

Wspólnym mianownikiem pandemii $u$ płazów jest niedawne pojawienie się patogenów związane $z$ nieumyślnym lub świadomym rozwleczeniem na skutek działalności człowieka. Pod tym względem XX w., czas zmasowanego transportu transkontynentalnego i przemian globalizacyjnych, był kluczowy dla rozwoju pandemii wśród płazów. Wielka trójka najgroźniejszych płazich patogenów ( $B d$, Bsal i $R v)$ posiada pewne cechy historii życiowych (ang. life history traits), które stanowia o ich ogromnych zdolnościach inwazyjnych: szerokie spektrum żywicieli, rozród klonalny (bezpłciowy), olbrzymi potencjał rozrodczy oraz dyspersje poprzez kontakt bezpośredni (np. podczas godów płazów) i pośredni (głównie w wodzie, a także na lądzie za pośrednictwem skraplającej się pary wodnej).

Pojawienie się patogenu $\mathrm{w}$ środowisku życia płaza nie jest równoznaczne $z$ infekcja i niechybna śmiercia osobnika. Odpowiedź gospodarza na infekcje zależy od jego oporności na infekcję i tolerancji po wniknięciu patogenu. Te $z$ kolei zależą od wielu czynników endogennych (Ryc. 3), jak np. od tła immunogenetycznego gospodarza (SAVAGE i współaut. 2016), mikrobiomu skóry (REBOLLAR i współaut. 2020) oraz współwystępujących infekcji (HERCZEG i współaut. 2021). Bardzo istotne sa także czynniki środowiskowe. Zakres termiczny optymalnego wzrostu obu gatunków Batrachochytrium jest dość wąski $\left(17-25^{\circ} \mathrm{C}\right.$ dla $B d, 10-15^{\circ} \mathrm{C}$ dla $B s a l$, a patogeny gina $\mathrm{w}$ temperaturze bliskiej $30^{\circ} \mathrm{C}$ (PIOTROWSKI i współaut. 2004, MARTEL i współaut. 2013, BLOOI i współaut. 2015). Siedliska okresowo wysychajace, np. chętnie odwiedzane przez płazy drobne zbiorniki wodne, ograniczaja retencję patogenów w środowisku, gdyż wszystkie omawiane patogeny są wrażliwe na brak wody. Przebieg infekcji warunkują również cechy samego organizmu chorobotwórczego. W przypadku $B d$ i $R v$ występują warianty o różnych genotypach warunkujących odmienna zjadliwość (BECKER i współaut. 2017, DUfFUs i wspó1aut. 2015). Ważne jest również synergiczne (wzajemnie wzmacniające się lub osłabiaja- 


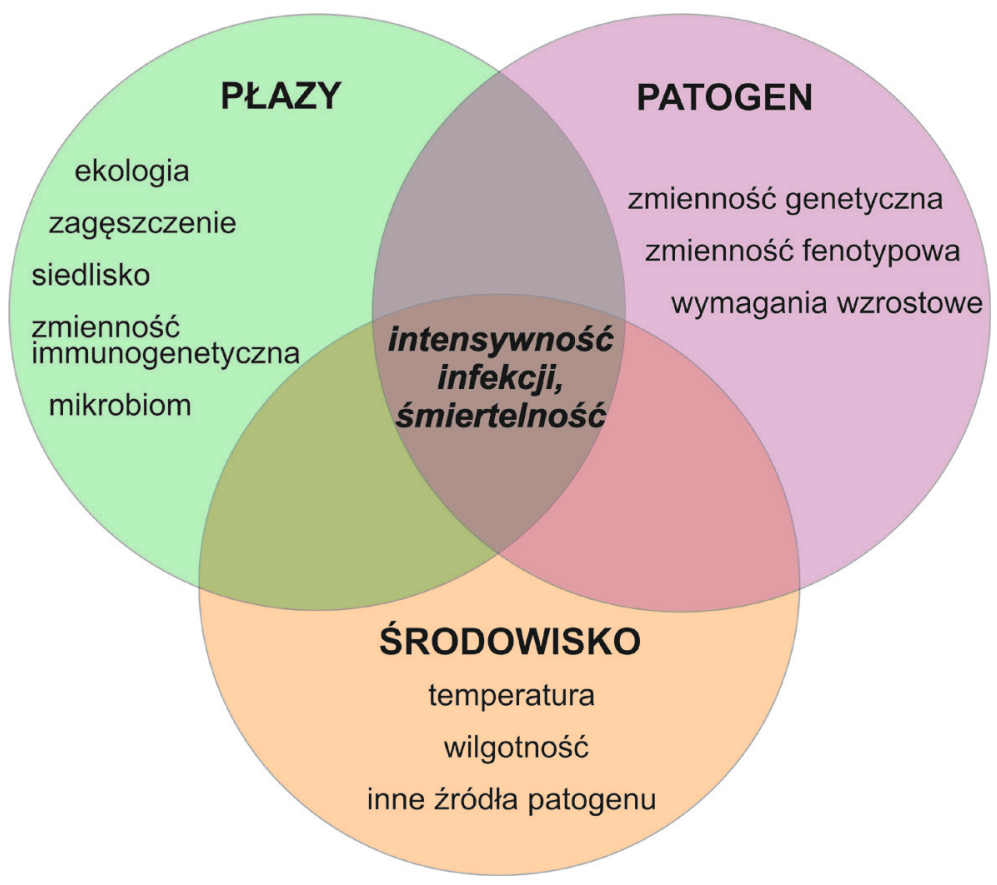

Ryc. 3. Interakcja pomiędzy cechami żywiciela-płaza, genotypem i fenotypem patogenu oraz czynnikami środowiska w przypadku infekcji Batrachochytrium dendrobatidis u płazów. Intensywność infekcji, determinująca śmiertelność osobniczą, wynika z synergicznego działanie różnych czynników (wg LIPS 2016, zmieniona, za zgoda The Royal Society Publishing).

ce) działanie patogenów i innych czynników szkodliwych dla płazów. Zmiany klimatyczne mogą przesunać temperaturę otoczenia w kierunku optymalnym dla rozwoju organizmów chorobotwórczych (ROLLINS-SMITH 2017). Niektóre zwiazki organiczne i mineralne stosowane $\mathrm{w}$ rolnictwie moga zmieniać skład mikrobiomu bakteryjnego skóry płazów, czyniąc je bardziej podatnymi na wnikanie patogenów (MCCOY i PERALTA 2018). Niedawno wykazany zwiąek pomiędzy nawożeniem stawów rybnych obornikiem pochodzacym $z$ trzody chlewnej a wyższą częstością $B d$ u płazów zamieszkujacych te zbiorniki, potwierdza te przypuszczenia (PREUSS i współaut. 2020). Obornik, zanieczyszczając zbiornik potężna dawka azotu i fosforu, zmienia skład bakterioplanktonu w wodzie, co $z$ kolei modyfikuje mikrobiom bakteryjny na powierzchni skóry płazów, czyniąc je bardziej podatnymi na infekcje $B d$. Te przykłady pokazuja, że interakcje w układzie patogen-żywiciel-środowisko sa skomplikowane i trudne do przewidzenia (LIPS 2016, FISHER i GARNER 2020) (Ryc. 3).

Czy zatem płazy skazane sa na zagładę? W krótszej perspektywie czasowej $z$ pewnością dojdzie do kolejnych masowych zaników płazów na skutek pojawiania się patogenów w populacjach, które nigdy wcześniej się $z$ nimi nie zetknęły. Może również dojść do intensyfikacji obecnego poziomu infekcji i wyższej śmiertelności w wyniku pogorszenia się warunków bytowania płazów. W dłuższej perspektywie pozostaje szansa na pojawienie się ewolucyjnej odpowiedzi żywicieli w postaci wzmożonej odporności lub tolerancji na infekcje. Badania porównawcze i laboratoryjne udokumentowały istnienie populacji płazów posiadających warianty głównego układu zgodności tkankowej (MHC-II), warunkujące mniejsza podatność na $B d$ (BATAILLE i współaut. 2015). Badania nad naturalna populacja żaby Lithobates yavapaiensis wykazały wzrost częstości korzystnego wariantu MHC-II i powiąanej wyższej przeżywalności osobników tego gatunku w obliczu infekcji Bd (SAVAGE i ZAMUDIO 2016). Z koewolucja płazów i ich patogenów wiąże się nadzieje na przetrwanie przynajmniej niektórych podatnych na infekcję gatunków. Jednak adaptacja do nowego patogenu jest procesem długotrwałym, mierzonym w pokoleniach. Jest więc wysoce prawdopodobne, że wiele populacji płazów wyginie zanim dojdzie $\mathrm{u}$ nich do adaptatywnej odpowiedzi układu immunologicznego. Pod tym katem, badania nad rozmieszczeniem i zjadliwością różnych szczepów BdGPL (GREENER i współaut. 2020), wydają się szczególnie ciekawe. GREENER i współaut. (2020) wykazali, iż niektóre szczepy BdGPL $z$ północnej Europy charakteryzuja się niewielka wirulencja i nie wywołuja chytridiomikozy. Badania laboratoryjne pokazały, że kontakt populacji płazów, które wcześniej nie zetknęły się $z B d$, ze szczepa- 
mi o niskiej wirulencji może je uodpornić na szczepy BdGPL o większej zjadliwości, a także na infekcję Bsal (niestety nie dotyczy to salamander plamistych). Obecność mniej zjadliwych, hipowirulentnych szczepów może zatem zwiększyć przeżywalność płazów narażonych na infekcję bardziej zjadliwymi formami patogenów. Nowe informacje dotyczace epidemiologii najlepiej poznanego patogenu - $B d$, a także wiele dobrze udokumentowanych przykładów szybkiego tempa adaptacji u płazów (PABIJAN i współaut. 2020) sa powodem ostrożnego optymizmu w rozważaniach nad losem tej grupy zwierzat w trakcie wyniszczajacych je pandemii.

\section{CO MOŻEMY ZROBIĆ?}

Istnieje szereg działań, które możemy podjać indywidualnie oraz jako społeczność państwa członkowskiego UE, w celu powstrzymania płazich chorób zakaźnych. Najbardziej skuteczne i możliwe do wykonania sa zalecenia prewencyjne. Dotycza one niedopuszczenia do rozprzestrzenienia się patogenów lub jego ograniczenia w największym możliwym stopniu. Zalecenia te sa szczególnie ważne w przypadku Bsal, którego pojawienie się i ekspansja w Europie zachodniej nastapiły niedawno. Sa istotne również w przypadku rozpowszechnionych już $B d$ i $R v$, ze względu na odmienne zjadliwości rozmaitych form tych patogenów i wynikajace $z$ tego różnice w poziomie zagrożenia dla płazów.

W celu zmniejszenia ryzyka przeniesienia patogenów zaleca się stosowanie szeregu działań prewencyjnych (THOMAs i współaut. 2019). Ograniczenie lub całkowity zakaz handlu płazami ma największe znaczenie prewencyjne w przypadku krajów, na terenie których nie stwierdzono jeszcze obecności patogenów, zwłaszcza Bsal. Regulacja prawna globalnego handlu płazami może uchronić kolejne populacje przed pojawieniem się organizmów chorobotwórczych (O’HANLON i współaut. 2020). Na terenie Unii Europejskiej od 2018 r. obowiazuje decyzja Komisji UE nr 2018/320, regulująca handel płazami w zwiazku $z$ rozprzestrzenianiem się Bsal (EUR-Lex, https://eur-lex. europa.eu/legal-content/PL/TXT/?uri=CELEX\%3A32018D0320). W Polsce w 2021 r. Generalna Dyrekcja Ochrony Środowiska (https://www.gov.pl/web/gdos/rekomendacje-w-zakresie-zapobiegania-i-rozprzestrzeniani a-sie-chorob-rodzimych-gatunkow-plazow-i-gadow), w oparciu o zalecenia Komisji Europejskiej, a także Stałego Komitetu Konwencji Berneńskiej, również wydała zalecenia dotyczące zapobiegania i rozprzestrzeniania się chorób rodzimych gatunków płazów i gadów.
Wszystkie te dokumenty skupiają się na ograniczeniu rozprzestrzeniania najbardziej niebezpiecznych patogenów: $B d$, Bsal i $R v$. Należy również zwrócić uwage na potencjalne źródła patogenów w postaci prywatnych hodowli płazów. Inwentaryzacja i diagnostyka zwierzą w niewoli mogłaby ograniczyć międzygatunkowe rozprzestrzenianie patogenów (PASMANS i współaut. 2017). Istotnym elementem działań prewencyjnych jest również bioasekuracja podczas badań terenowych i laboratoryjnych, a także w trakcie rekreacji na terenach występowania płazów (LOYAU i ScHMELLER 2017). Zalecane jest odkażanie rąk, sprzętu badawczego oraz butów i elementów ubioru mającego kontakt bezpośrednio $z$ płazami i otoczeniem (VAN RoOIJ i współaut. 2017). Należy unikać niepotrzebnego odławiania czy przetrzymywania płazów, a w przypadku badań terenowych dotykania zwierząt bez rękawiczek ochronnych, zmienianych po każdym osobniku (THOMAS i współaut. 2020). Powyższe działania sa ważnymi czynnikami ograniczajaccymi rozprzestrzenianie niebezpiecznych patogenów na nowe tereny. Istotny jest również stały monitoring populacji pod względem nagłego wzrostu śmiertelności oraz przesiewowe badania diagnostyczne w kierunku obecności patogenów (THOMAs i współaut. 2019). Konieczne jest opracowanie szczegółowego planu działania przystosowanego do lokalnych uwarunkowań przyrodniczych i społecznych w przypadku wystapienia masowej śmiertelności płazów w Polsce, zwłaszcza zwiąanej $z$ możliwym pojawieniem się Bsal na terenie kraju. Ważne jest również popularyzowanie wiedzy o patogenach płazów, zarówno w środowisku naukowym prowadzacym badania terenowe, jak i wśród osób rekreacyjnie przebywajacych na obszarach zagrożonych obecnością patogenów.

W przypadku pojawienia się danego patogenu na nowym stanowisku należy przede wszystkim podjać działania mające na celu zmniejszenie jego negatywnego wpływu na populacje oraz ograniczenie dalszej transmisji (THOMAS i współaut. 2019, GILBERT i współaut. 2020). Moga one obejmować próby wyeliminowania patogenu ze środowiska, np. za pomoca środków chemicznych (fungicydy) (GEIGER i współaut. 2017). Innym rozwiazaniem może być usunięcie $z$ danego obszaru wszystkich potencjalnych nosicieli, w powiazaniu $z$ izolacja miejsca pojawienia się patogenu, za pomoca fizycznych barier uniemożliwiających przemieszczanie się płazów i innych organizmów (THOMAs i współaut. 2019). Proponowano również zabiegi manipulujace właściwościami ekosystemów, w których doszło do infekcji, np. przez osuszanie zbiorników wodnych będacych siedliskiem dysper- 
syjnych form patogenów, podwyższanie temperatury wody poprzez usuwanie zacienienia zbiorników (BOSCH i współaut. 2015), a także wprowadzenie do środowiska mikroorganizmów żerujących na patogenach (SCHMELLER i współaut. 2014). Wdrożenie wyżej wymienionych zaleceń jest skomplikowane logistycznie, wią̇e się $z$ dużymi kosztami, i bywa etycznie kontrowersyjne, zwłaszcza jeśli dotyczy uśmiercania dużej liczby płazów (THOMAS i współaut. 2019). Co ważniejsze, ich zastosowanie nie gwarantuje wyeliminowania patogenu ze środowiska. Jak dotychczas, pomimo wielu prób, znamy tylko jeden przykład usunięcia $B d$ ze środowiska (za pomoca fungicydu) zakończony sukcesem (BOScH i współaut. 2015). Niedawna próba usunięcia nowego ogniska Bsal w Hiszpanii, pomimo skoordynowanych działan bioasekuracyjnych, manipulacji środowiskiem, usuwania żywicieli i wzmożonym nadzorem epidemiologicznym, niestety nie powiodła się - po prawie dwóch latach intensywnych działan Bsal nadal infekuje płazy ogoniaste $\mathrm{w}$ tym miejscu (MARTEL i współaut. 2020).

Zdaniem niektórych badaczy, usuwanie patogenów płazich na większą skalę jest praktycznie niemożliwe (CANESSA i współaut. 2018, THOMAS i współaut. 2019, FISHER i GARNER 2020). Dlatego tak istotne jest doskonalenie i wprowadzenie skutecznych działań zapobiegajacych pojawieniu się patogenów w nowych lokalizacjach, a także wdrożenie zasad postępowania epidemiologicznego w miejscach, w których doszło do masowej śmiertelności płazów po pojawieniu się Bsal lub zjadliwych form innych patogenów. Opracowano w tym celu ogólnoeuropejski plan działania w zwiazku $\mathrm{z}$ ekspansja Bsal (ang. „Bsal Action Plan”) (GILBERT i współaut. 2020), stanowiacy kompendium możliwych działań pre- i post-inwazyjnych w przypadku tego patogenu. W Polsce Grupa Robocza ds. Chorób Płazów (http://zap-uj.pl/choroby.html) zbiera informacje na temat rozmieszczenia patogenów płazich w kraju, przypadków masowej śmiertelności płazów wywołanej chorobami, a także prowadzi diagnostykę płazów pod katem obecności chorobotwórczych organizmów. Istnieje możliwość zgłoszenia niepokojących obserwacji zebranych zarówno w trakcie badań terenowych, jak i rekreacyjnego spaceru na obszarach występowania płazów, poprzez specjalny formularz (http://zap-uj.pl/formularz. html) lub droga mailowa bezpośrednio do autorów niniejszego artykułu. Szybkie wykrywanie patogenów jest kluczowe dla skutecznego wprowadzania działań ochronnych płazów, a także umożliwia zastosowanie praktyk prewencyjnych na obszarze zagrożonym pojawieniem się patogenów.

\section{Streszczenie}

Płazy to jedna $z$ najbardziej zagrożonych grup zwierząt na świecie, głównie ze względu na niszczenie ich siedlisk przez człowieka. W dobie koronawirusowej pandemii warto wspomnieć również o chorobach, z którymi ta grupa kręgowców mierzy się już od wielu lat. Choroby zakaźne wywołane przez mikroskopijne grzyby pasożytnicze Batrachochytrium dendrobatidis i B. salamandrivorans, a także różne formy ranawirusów (Ranavirus) stanowią ogromne zagrożenie dla płazów, dziesiątkując ich populacje na całym świecie, także w Europie. Przedstawiamy najnowsze doniesienia na temat rozmieszczenia najważniejszych patogenów płazów, w tym także $z$ Polski, oraz perspektywy zachowania płazów w obliczu trwających pandemii. Podsumowujemy również najistotniejsze działania prewencyjne, ograniczające transmisje patogenów, a także przytaczamy przykłady działań mających eliminować chorobotwórcze organizmy ze środowiska. Artykuł ma na celu zwiększenie świadomości społecznej dotyczacej patogenów, mogącej wpłynąc na podjęcie skutecznych działań zmniejszających negatywne skutki pandemii wśród płazów.

\section{LITERATURA}

Ariel E., Kielgast J., Svart H. E., Larsen K., TAPIOVAARA H., JENSEN B. B., HOLOPAINEN R., 2009. Ranavirus in wild edible frogs Pelophy lax $k l$. esculentus in Denmark. Dis. Aquat. Org. 85, 7-14

Balseiro A., Dalton K. P., Del CerRo A., MARQUeZ I., PARRA F., PRIETO J. M., CASAIS R., 2010. Outbreak of common midwife toad virus in alpine newts (Mesotriton alpestris cyreni) and common midwife toads (Alytes obstetricans) in Northern Spain: A comparative pathological study of an emerging ranavirus. Vet. J. 186, 256-258.

Bataille A., Cashins S. D., Grogan L., SkerRatT L. F., Hunter D., MCFADDEN M., SCHEEle B., BRANnelly L. A., Macris A., HaRlow P. S., BELl S., BERGER L., WALDMAN B., 2015. Susceptibility of amphibians to chytridiomycosis is associated with MHC class II conformation. Proc. Royal Soc. B: Biol. Sci. 282, doi: $10.1098 / \mathrm{rspb} .2014 .3127$

Becker C. G., GREenspan S. E., TRACy K. E. DASH J. A., LAMBERTINI C., JENKINSON T. S., LEITE D. S., TOledo L. F., LONGCORE J. E., JAMESE T. Y., ZAMUdiO K. R., 2017. Variation in phenotype and virulence among enzootic and panzootic amphibian chytrid lineages. Fungal Ecol. 26, 45-50.

Berger L., Speare R., Skerratt L. F., 2005. Distribution of Batrachochytrium dendrobatidis and pathology in the skin of green tree frogs Litoria caerulea with severe chytridiomycosis. Dis. Aquat. Org. 68, 65-70.

Beukema W., Martel A., NGuyen T. T., Goka K., Schmeller D. S., Yuan Z., LaKing A. E., NGuYen T. Q., Lin C., Shelton J., LOYAU A., PASMANS A. L. F., 2018. Environmental context and differences between native and invasive observed niches of Batrachochytrium salamandrivorans affect invasion risk assessments in the Western Palaearctic. Diver. Distribut. 24, 1788-1801.

Blooi M., Martel A., Haesebrouck F., VercamMEN F., BONTE D., PASMANS F., 2015. Treatment of urodelans based on temperature dependent infection dynamics of Batrachochytrium salamandrivorans. Scient. Rep. 5, 1-4. 
Bosch J., Martínez-Solano I., 2006. Chytrid fungus infection related to unusual mortalities of Salamandra salamandra and Bufo bufo in the Penalara Natural Park, Spain. Oryx 40, 84-89.

Bosch J., MARTÍNEZ-SOlano I., GaRcÍA-PARÍS M., 2001. Evidence of a chytrid fungus infection involved in the decline of the common midwife toad (Alytes obstetricans) in protected areas of central Spain. Biol. Conserv. 97, 331-337.

Bosch J., SANChEZ-Tomé E., FERnándeZ-Loras A., Oliver J. A., Fisher M. C., GARner T. W. J., 2015. Successful elimination of a lethal wildlife infectious disease in nature. Biol. Lett. 11, doi: $10.1098 / \mathrm{rsbl} .2015 .0874$

Bosch J., MARTEL A., SOPNIEWski J., THumsová B., Ayres C., Scheele B. C., Velo-Antón G., PASMANS F., 2021. Batrachochytrium salamandrivorans threat to the Iberian urodele hotspot. J. Fungi 7, doi.org/10.3390/jof7080644.

BYRNE A. Q., VREDENBURG V. T., MARTEL A., Pasmans F., Bell R. C., Blackburn D. C., BletzH M. C., BOSChI J., BRIGGS C. J., BROWNL R. M., CATENAZZI A., FAMILIAR LÓPEZ M. i współaut., 2019. Cryptic diversity of a widespread global pathogen reveals expanded threats to amphibian conservation. Proc. Natl. Acad. Sci. USA 116, 20382-20387.

Canessa S., Bozzuto C., Campbell Grant E. H., Cruickshank S. S., Fisher M. C., KoELla J. C., LÖTTERS S., MARTEl A., PASMANS F., Scheele B. C., Spitzen-VAN Der SluiJs A., STEINFARTZ S., SCHMIDT B. R., 2018. Decision $\square$ making for mitigating wildlife diseases: From theory to practice for an emerging fungal pathogen of amphibians. J. Appl. Ecol. 55, 1987-1996.

Ceballos G., Ehrlich P. R., Barnosky A. D., García A., PRingle R. M., PAlmer T. M., 2015. Accelerated modern human-induced species losses: Entering the sixth mass extinction. Sci. Advances 1, e1400253.

Ceballos G., Ehrlich P. R., Raven P. H., 2020. Vertebrates on the brink as indicators of biological annihilation and the sixth mass extinction. Proc. Natl. Acad. Sci. USA 117, $13596-$ 13602.

Collins J. P., 2010. Amphibian decline and extinction: what we know and what we need to learn. Dis. Aquat. Org. 92, 93-99.

COLlins J. P., STORFER A., 2003. Global amphibian declines: sorting the hypotheses. Divers. Distribut. 9, 89-98.

DASZAK P., CUNNingham A. A., HyatT A. D., 2003. Infectious disease and amphibian population declines. Divers. Distribut. 9, 141-150.

Duffus A. L., WaltzeK T. B., STÖHR A. C., ALLENDER M. C., GOTESMAN M., WhitTington R. J., Hick P., Hines M. K., MARSCHANG R. E., 2015. Distribution and host range of ranaviruses. [W:] Ranaviruses. Lethal Pathogens of Ectothermic Vertebrates. GRAY M. J., CHINCHAR V. G. (red.). Springer, Cham, 9-57.

EARL J. E., CHANEY J. C., SUTTON W. B., LILlard C. E., Kouba A. J., Langhorne C., Krebs J., Wilkes R. P., Hill R. D., Miller D. L., GRAY M. J., 2016. Ranavirus could facilitate local extinction of rare amphibian species. Oecologia $182,611-623$.

FARRER R. A., WEINERT L. A., Bielby J., GARNeR T. W., BallouX F., Clare F., BOSCH J., CunNinghaM A. A., WELDON C., DU PREEZ L. H., ANDERSON L., KOSAKOVSKY POND S. L., SHAHAR-Golana R., HENK D. A., FISHER M. C., 2011. Multiple emergences of genetically diverse amphibian-infecting chytrids include a globalized hypervirulent recombinant lineage. Proc. Natl. Acad. Sci. USA 108, 18732-18736.

FEDER M. E., BURGGREN W. W., 1992. Environmental physiology of the amphibians. University of Chicago Press, Chicago.

Fisher M. C., GARNER T. W., 2020. Chytrid fungi and global amphibian declines. Nat. Rev. Microbiol. 18, 332-343.

FRANKLINOS L. H. V., FERNANDEZ J. R. R., Hydeskov H. B., Hopkins K. P., Everest D. J., Cunningham A. A., Lawson B., 2018. Herpesvirus skin disease in free-living common frogs Rana temporaria in Great Britain. Dis. Aquat. Org. 129, 239-244.

Gallant A. L., Klaver R. W., CASPer G. S., LanNOO M. J., 2007. Global rates of habitat loss and implications for amphibian conservation. Copeia 2007, 967-979.

Geiger C. C., Bregnard C., Maluenda E., VoorDOUW M. J., SCHMIDT B. R., 2017. Antifungal treatment of wild amphibian populations caused a transient reduction in the prevalence of the fungal pathogen Batrachochytrium dendrobatidis. Sci. Rep. 7, doi: 10.1038/s41598017-05798-9.

Gilbert M. J., Spitzen-Van Der Sluids A. M., CANESSa S., Bosch J., Cunningham A. A., GrasSelli E., laudelout A., Lötters S., Miaud C., Salvidio S., Veith M., Martel A., Pasmans F., 2020. Mitigating Batrachochytrium salamandrivorans in Europe. Amphibia-Reptilia 40, 265-290.

GRANOFF A., CAME P. E., RAFFerty JR. K. A., 1965. The isolation and properties of viruses from Rana pipiens: their possible relationship to the renal adenocarcinoma of the leopard frog. Ann. NY Acad. Sci. 126, 237-255.

Gray M. J., Miller D. L., Hoverman J. T., 2009. Ecology and pathology of amphibian ranaviruses. Dis. Aquat. Org. 87, 243-266.

Green D. E., CONVERSE K. A., Schrader A. K., 2002. Epizootiology of sixty-four amphibian morbidity and mortality events in the USA, 1996-2001. Ann. NY Acad. Sci. 969, 323-339.

Greener M. S., Verbrugghe E., Kelly M., Blooi M., Beukema W., CANessa S., Carranza S., Croubels S., De TROYER N., FERNANDEZ-GiBERTEAU D., Goethals P., Lens L., Li Z., STEGeN G., STRUBbe D., VAN LEeUWEnBERG R., VAN PRAET S., VILA-ESCALE M., VERVAEKE M., Pasmans F., Martel A., 2020. Presence of low virulence chytrid fungi could protect European amphibians from more deadly strains. Nat. Commun. 11, 1-11.

GreEnspan S. E., CAlHoun A. J., LONGCORE J. E., LEVY M. G., 2012. Transmission of $\mathrm{Ba}$ trachochytrium dendrobatidis to wood frogs (Lithobates sylvaticus) via a bullfrog (L. catesbeianus) vector. J. Wildlife Dis. 48, 575-582.

GREENSPAN S. E., LAMBERTINI C., CARVAlHO T., James T. Y., TOledo L. F., HAdDAD C. F. B., BECKER C. G., 2018. Hybrids of amphibian chytrid show high virulence in native hosts. Sci. Rep. 8, 1-10.

Harmos K., Bosch J., Thumsová B., Martínez-SilVESTRE A., VElarde R., VOROS J., 2021. Amphibian mortality associated with chytridiomycosis in Central-Eastern Europe. Herpetology Notes 14, 1213-1218.

HeRCZEG D., UJSZEGI J., KÁSLer A., Holly D., HETTYEY A., 2021. Host-multiparasite interactions in amphibians: a review. Parasites Vectors $14,1-20$.

ISIDORO-AYZA M., LORCH J. M., GREAR D. A., WINZELER M., CALHOUN D. L., BARICHIVICH W. J., 2017. Pathogenic lineage of Perkinsea as- 
sociated with mass mortality of frogs across the United States. Sci. Rep. 7, doi:10.1038/ s41598-017-10456-1.

IUCN, 2021. The IUCN Red List of threatened species. Version 2020-3. https://www.iucnredlist.org.

Jancovich J. K., SteckleR N. K., Waltzek T. B. 2015a. Ranavirus taxonomy and phylogeny. [W:] Ranaviruses. Lethal Pathogens of Ectothermic Vertebrates. GRAY M. J., CHINCHAR V. G. (red.). Springer, Cham, 59-70.

JANCOVICH J. K., QIN Q., ZHANG Q. Y., CHINCHAR V. G., 2015b. Ranavirus replication: molecular, cellular, and immunological events. [W:] Ranaviruses. Lethal Pathogens of Ectothermic Vertebrates. GRAY M. J., CHINCHAR V. G. (red.). Springer, Cham, 105-139.

Kiesecker J. M., Blaustein A. R., Belden L. K., 2001. Complex causes of amphibian population declines. Nature 410, 681-684.

Kolby J. E., Smith K. M., Berger L., Karesh W. B., Preston A., Pessier A. P., Skerratt L. F., 2014. First evidence of amphibian chytrid fungus (Batrachochytrium dendrobatidis) and ranavirus in Hong Kong amphibian trade. PloS One 9, e90750.

KolendA K., NAJBAR A., OGIElska M., BALÁŽ V., 2017. Batrachochytrium dendrobatidis is present in Poland and associated with reduced fitness in wild populations of Pelophylax lessonae. Dis. Aquat. Org. 124, 241-245.

KRAUS F., 2015. Impacts from invasive reptiles and amphibians. Ann. Rev. Ecol. Evol. Syst. 46, 75-97.

Laking A. E., NGo H. N., Pasmans F., Martel A., NGUYEN T. T., 2017. Batrachochytrium salamandrivorans is the predominant chytrid fungus in Vietnamese salamanders. Sci. Rep. 7, $1-5$.

LASTRA GonZÁlez D., BALÁŽ V., SOlskÝ M., THumsová B., Kolenda K., NAJBAR A., NAJBAR B., KAUTMAN M., CHAJMA P., BALOGOVÁ M., VOJAR J., 2019. Recent findings of potentially lethal salamander fungus Batrachochytrium salamandrivorans. Emerg. Infect. Dis. 25, 1416-1418.

LiPS K. R., 2016. Overview of chytrid emergence and impacts on amphibians. Philosoph. Transact. Royal Soc. B: Biol. Sci. 371, doi: $10.1098 /$ rstb.2015.0465.

LongCORE J. E., Pessier A. P., Nichols D. K., 1999. Batrachochytrium dendrobatidis gen. et sp. nov., a chytrid pathogenic to amphibians. Mycologia 91, 219-227.

LOYAU A., SCHMEller D. S., 2017. Positive sentiment and knowledge increase tolerance towards conservation actions. Biodivers. Conserv. 26, 461-478

LÖTTERS S., VEITH M., WAGNER N., MARTEL A., PASMANS F., 2020. Bsal-driven salamander mortality pre-dates the European index outbreak. Salamandra 56, 239-242.

MCCOY K. A., PERALTA A. L., 2018. Pesticides could alter amphibian skin microbiomes and the effects of Batrachochytrium dendrobatidis. Front. Microbiol. 9, 748

MARTEl A., SPITZEN-VAN DER SluiJs A., BlOOI M., BerT W., Ducatelle R., Fisher M. C., Woeltues A., Bosman W., ChIERs K., BossuyT F., PASMANS F., 2013. Batrachochytrium salamandrivorans sp. nov. causes lethal chytridiomycosis in amphibians. Proc. Natl. Acad. Sci. USA $110,15325-15329$.

MARTEL A., VILA-ESCALE M., FERNÁNDEZ-GIBERTEAU D., Martinez-Silvestre A., Canessa S. Van Praet S., Pannon P., Chiers K., Ferran
A., KELly M., PICART M. i współaut., 2020. Integral chain management of wildlife diseases. Conserv. Lett. 13, doi.org/10.1111/ conl.12707.

Miaud C., Pozet F., Gaudin N. C. G., Martel A., PASmans F., LABRUT S., 2016a. Ranavirus causes mass dieoffs of alpine amphibians in the southwestern Alps, France. J. Wildlife Dis. $52,242-252$.

Miaud C., Dejean T., Savard K., Millery-Vigues A., VAlentini A., Gaudin N. C. G., Garner T. W., 2016b. Invasive North American bullfrogs transmit lethal fungus Batrachochytrium dendrobatidis infections to native amphibian host species. Biol. Invas. 18, 2299-2308.

Miller D. L., Pessier A. P., Hick P., WhitTington R. J., 2015. Comparative pathology of ranaviruses and diagnostic techniques. [W:] Ranaviruses. Lethal Pathogens of Ectothermic Vertebrates. GRAY M. J., CHINCHAR V. G. (red.). Springer, Cham, 171-208.

Nguyen T. T., VAN NGuYen T., ZIEgler T., PASMANS F., MARTEL A., 2017. Trade in wild anurans vectors the urodelan pathogen Batrachochytrium salamandrivorans into Europe. Amphibia-Reptilia 38, 554-556.

O'HANlON S. J., RieuX A., FARRER R. A., Rosa G. M., WALDMAN B., BATAILle A., KosCH T. A., MurRay K. A., Brankovics B., Fumagalli M., MARTIN M. D., WALES N. i współaut., 2018. Recent Asian origin of chytrid fungi causing global amphibian declines. Science 360, 621627.

OHST T, GRÄSER Y., PLÖTNER J, 2013, Batrachochytrium dendrobatidis in Germany: dis tribution, prevalences, and prediction of high risk areas. Dis. Aquat. Org. 107, 49-59.

ORIGGi F. C., SCHMIDT B. R., LOHMANN P., OTTEN P., AKDesir E., Gaschen V., Aguilar-Bultet L., T. WAHli T., SATTler U., StOFFEL M. H., 2017. Ranid herpesvirus 3 and proliferative dermatitis in free-ranging wild common frogs (Rana temporaria). Vet. Pathol. 54, 686-694.

PabiJan M., Palomar G., Antunes B., Antol W., ZIELIŃSKI P., BABIK W., 2020. Evolutionary principles guiding amphibian conservation. Evol. Applic. 13, 857-878.

PALOMAR G., JAKÓBIK J., Bosch J., KOlEndA K., KACZMARSKI M., JOŚKO P., ROCES-DíA J. V., STACHYRA P., THUMSOVÁ B., ZIELIŃSKI P., PABIJAN M., 2021. Emerging infectious diseases of amphibians in Poland: distribution and environmental drivers. Dis. Aquat. Org. 147, 1-12.

PASMANS F., BogaerTs S., BRAECKMAN J., CUNNINGHAM A. A., HELlEBUYCK, T., GRIFFITHS A., SPARREBOOM M., SCHMIDT B. R., MARTEL A., 2017. Future of keeping pet reptiles and amphibians: towards integrating animal welfare, human health and environmental sustainability. Vet. Rec. 181, 450-450.

PIOTROWSKI J. S., ANNIS S. L., LONGCORE J. E., 2004. Physiology of Batrachochytrium dend robatidis, a chytrid pathogen of amphibians. Mycologia 96, 9-15.

Preuss J. F., Greenspan S. E., Rossi E. M., LUCAS Gonsales E. M., NEely W. J., VAliati V. H., Woodhams D. C., Guilherme Becker C., TOZETTI A. M., 2020. Widespread pig farming practice linked to shifts in skin microbiomes and disease in pond-breeding amphibians. Environ. Sci. Technol. 54, 11301-11312.

PRICE S. J., GARNeR T. W., NiChOls R. A., BALlouX F., Ayres C., De Alba A. M. C., Bosch J., 2014. Collapse of amphibian communities due to an introduced Ranavirus. Curr. Biol. 24, 2586-2591. 
Price S. J., Garner T. W., Cunningham A. A., LANGTON T. E., NichOlS R. A., 2016. Reconstructing the emergence of a lethal infectious disease of wildlife supports a key role for spread through translocations by humans. Proc. Royal Soc. B: Biol. Sci. 283, doi: 10.1098/rspb.2016.0952.

Price S. J., ARiel E., Maclaine A., Rosa G. M., GRAY M. J., BRUNNER J. L., 2017b. From fish to frogs and beyond: impact and host range of emergent ranaviruses. Virology 511, 272-279.

Rebollar E. A., Martínez-Ugalde E., Orta A. H., 2020. The amphibian skin microbiome and its protective role against chytridiomycosis. Herpetologica 76, 167-177.

Rollins-Smith L. A., 2017. Amphibian immunitystress, disease, and climate change. Develop. Compar. Immunol. 66, 111-119.

Rosa G. M., SABino-Pinto J., Laurentino T. G., Martel A., Pasmans F., Rebelo R., Griffiths R. A., STÖhr A. C., MARSchang R. E., PRICE S. J., GARNER T. W. J., Bosch J., 2017. Impact of asynchronous emergence of two lethal pathogens on amphibian assemblages. Sci. Rep. 7, 1-10.

Rosenblum E. B., James T. Y., ZAmudio K. R., POORTEN T. J., ILUT D., RODRIGUEZ D., EASTMAN J. M., RICHARDS-HRDLICKA K., JONESON S., JENKINSON T. S., LONGCORE J. F., PARRA OlEA G., Toledo L. F., Arellano M. L., Medina E. M., RESTREPO S., Flechas S. V., Berger L., BRIGG C. J., STAJICH J. E., 2013. Complex history of the amphibian-killing chytrid fungus revealed with genome resequencing data. Proc. Natl. Acad. Sci. USA 110, 9385-9390.

SAvage A. E., ZAMUdiO K. R., 2016. Adaptive tolerance to a pathogenic fungus drives major histocompatibility complex evolution in natural amphibian populations. Proc. Royal Soci. B: Biol. Sci. 283, doi: 10.1098/rspb.2015.3115.

Savage A. E., Terrell K. A., Gratwicke B., MatTHEus N. M., Augustine L., Fleischer R. C., 2016. Reduced immune function predicts disease susceptibility in frogs infected with a deadly fungal pathogen. Conserv. Physiol. 4, doi: 10.1093/conphys/cow011.

ScheEle B. C., Pasmans F., Skerratt L. F., Berger L., Martel A. N., Beukema W., CANESSA S., 2019. Amphibian fungal panzootic causes catastrophic and ongoing loss of biodiversity. Science 363, 1459-1463.

SCHMEller D. S., BloOI M., MARTEl A., GARner T. W. J., Fisher M. C., AZEMAR F., Clare F. C., LeCleRC C., JÄGER L., GuevarA-Nieto M., LoYau A., PASMANS F., 2014. Microscopic aquatic predators strongly affect infection dynamics of a globally emerged pathogen. Curr. Biol. 24, 176-180.

Schmeller D. S., Utzel R., Pasmans F., MARTEL A., 2020. Batrachochytrium salamandrivorans kills alpine newts (Ichthyosaura alpestris) in southernmost Germany. Salamandra 56, 230232.

Schulz V., Schulz A., Klamke M., Preissler K., Sabino-Pinto J., MÜSKen M., SChlÜPMANN M., HELDT L., KAMPRAD F., ENSS J., SCHWEINSBERG M., Virgo J., RAU H., Veith M., LÖTTERS S., WAGNer N., Steinfartz S., Vences M., 2020. Batrachochytrium salamandrivorans in the Ruhr District, Germany: history, distribution, decline dynamics and disease symptoms of the salamander plague. Salamandra 56, 189214.
Spitzen-VAn Der SluiJs A., Martel A., AsselberGHS J., Bales E. K., Beukema W., Bletz M. C., LÖTTERS S., 2016. Expanding distribution of lethal amphibian fungus Batrachochytrium salamandrivorans in Europe. Emerg. Infect. Dis. 22, 1286.

Stegen G., Pasmans F., Schmidt B. R., Rouffaer L. O., VAN PRAET S., Schaub M., CANESSA S., Laudelout A., Kinet T., Adriaensen C., HAESEBROUCK F., BeRT W., BOSSUYT F., MARTEL A., 2017. Drivers of salamander extirpation mediated by Batrachochytrium salamandrivorans. Nature 544, 353-356.

Sura P., JANUlis E., PROFUS P., 2010. Chytridiomikoza - śmiertelne zagrożenie dla płazów. Chrońmy Przyrodę Ojczystą 66, 406-421.

Teacher A. G. F., Cunningham A. A., Garner T. W. J., 2010. Assessing the long $\square$ term impact of Ranavirus infection in wild common frog populations. Anim. Conserv. 13, 514-522.

Thein J., RECK U., DitTRICH C., MARTEL A., Schulz V., Hansbauer G., 2020. Preliminary report on the occurrence of Batrachochytrium salamandrivorans in the Steigerwald, Bavaria, Germany. Salamandra 56, 227-229.

THOMAS V., WANG Y., VAN ROOIJ P., VerbRUGGHE E., BALÁŽ V., Bosch J., Cunningham A. A., Fisher M. C., GARNER T. W. J., GILBERT M. J., Grasselli E., Kinet T., Laudelout A., LÖTTERS S., LOYAU A. i współaut., 2019. Mitigating Batrachochytrium salamandrivorans in Europe. Amphibia-Reptilia 40, 265-290.

Thomas V., Van RooiJ P., Meerpoel C., Stegen G., Wauters J., VANHAEcKe L., Martel A., PASMANS F., 2020. Instant killing of pathogenic chytrid fungi by disposable nitrile gloves prevents disease transmission between amphibians. PloS One, 15, e0241048.

THuMSOVÁ B., GONZÁLEZ-Miras E., FAULKNER S. C., Bosch J., 2021. Rapid spread of a virulent amphibian pathogen in nature. Biol. Invasions 23, 3151-3160

Van RooiJ P., Pasmans F., Coen Y., Martel A., 2017. Efficacy of chemical disinfectants for the containment of the salamander chytrid fungus Batrachochytrium salamandrivorans. PLoS One, 12, e0186269.

VÖRÖS J., HERCZEG D., FÜlÖP A., GÁl J. T., DÁN Á., HARMOS K., Bosch J., 2018. Batrachochytrium dendrobatidis in Hungary: an overview of recent and historical occurrence. Acta Herpetol. 13, 125-140.

Voyles J., Young S., Berger L., CAMpbell C., Voyles W. F., Dinudom A., COOK D., WebB R., AlFORD R. A., SKERRATT L. F., SPEARE R., 2009. Pathogenesis of chytridiomycosis, a cause of catastrophic amphibian declines. Science $326,582-585$.

VRedenburg V. T., Felt S. A., Morgan E. C., MCNAlly S. V., Wilson S., GREen S. L., 2013. Prevalence of Batrachochytrium dendrobatidis in Xenopus collected in Africa (1871-2000) and in California (2001-2010). PLoS One 8, e63791.

Weldon C., Du Preez L. H., Hyatt A. D., Muller R., SPEARE R., 2004. Origin of the amphibian chytrid fungus. Emerg. Infect. Dis. 10, 21002105.

WeLLS K. D., 2010. The ecology and behavior of amphibians. University of Chicago Press, Chicago. 
Kosmos Vol. 70, 3, 505-518, 2021

\section{JoAnNa Jakóbik, MacieJ PABIJAn}

Department of Comparative Anatomy, Institute of Zoology and Biomedical Research, Faculty of Biology, Jagiellonian University, Gronostajowa Str., 30-387 Kraków,E-mail: maciej.pabijan@uj.edu.pl

\section{AMPHIBIAN PANDEMIC DISEASES}

\section{Summary}

Amphibians are one of the most threatened groups of organisms on Earth, mainly due to the destruction of their habitats by humans. During the coronavirus epidemic, it is important to emphasize that contagious diseases have also ravaged amphibian populations for many decades. Disease caused by microscopic, skin-infesting fungi Batrachochytrium dendrobatidis and B. salamandrivorans, as well as various forms of ranavirus (Ranavirus), have decimated amphibian populations around the world and are therefore of major conservation concern. In this work, we summarize new information on the distribution of the most important amphibian pathogens, including those from Poland, and offer perspective for amphibian conservation in the midst of these pandemics. We outline the most important preventive measures against pathogens spread, and provide examples of potential eradication procedures. Our aim is to increase public awareness of amphibian diseases, which in turn may support broader actions directed at mitigating the consequences of pathogen's expansion.

Key words: Amphibia, amphibian pathogens, Batrachochytrium, chytridiomycosis, invasive species, infection, coevolution, Ranavirus 